\title{
PEMBERDAYAAN MASYARAKAT BERBASIS KELAUTAN DENGAN PENGOLAHAN KARAGINAN DI DESA TIHENGO KECAMATAN PONELO KEPULAUAN KABUPATEN GORONTALO UTARA
}

\author{
Community Empowerment Based On Marine With Caraginant \\ Processing In Tihengo Village District Ponelo Kepulauan,Subdistrict Gorontalo North
}
Ika Okhtora Angelia' ${ }^{1)}$, Abdul Azis Hasan ${ }^{2)}$, Adnan Engelen ${ }^{3)}$, Arif Murtaqi ${ }^{4)}$, Wila Rumina Nento ${ }^{5}$ )

1, 2, 3, 4, 5)Staf Pengajar Program Studi Teknologi Hasil Pertanian, Politeknik Gorontalo

Jl. Muchlis Rahim Desa Panggulo, Kec. Botupingge, Kab. Bone Bolango, Prov. Gorontalo

Email : Email: ikaokhtora@poligon.ac.id

\begin{abstract}
ABSTRAK
Hasil laut yang dihasilkan di Provinsi Gorontalo Utara diantaranya adalah ikan, udang, lobster, kepiting dan rumput laut. Rumput laut merupakan komoditas kelautan yang paling banyak diminati. Namun inovasi bagaimana cara mengolah rumput laut menjadi produk olahan yang berdaya jual tinggi masih belum banyak diketahui oleh para nelayan. Daerah penghasil rumput laut terbesar di Provinsi Gorontalo ada di Kabupaten Gorontalo Utara pusatnya di Kecamatan Ponelo Kepulauan. Kegiatan Pengabdian Kepada Masyarakat ini bertujuan untuk melakukan edukasi kepada kelompok pengolahan rumput laut di Desa Tihengo yang merupakan desa penghasil rumput laut terbesar di Gorontalo Utara dalam rangka menunjukkan bagaimana metode yang benar dalam memanfaatkan rumput laut menjadi olahan makanan yang bernilai jual tinggi sehingga terbangun sikap kemandirian warga dengan membuat produk itu sendiri melalui kelompok binaan masyarakat. Sehingga selain lingkungan menjadi bersih diharapkan masing-masing kepala keluarga memiliki usaha sampingan dari hasil penjualan olahan rumput laut tersebut sehingga bisa dijadikan tambahan pendapatan keluarga dan mampu mengurangi tingkat kemiskinan seperti yang diharapkan pemerintah pusat maupun daerah. Pelatihan yang dilakukan meliputi pengolahan produk berbahan dasar rumput laut yaitu pelatihan pembuatan karaginan. Hasil akhir yang telah didapatkan dari kegiatan pengabdian ini adalah masyarakat menjadi terampil dalam melakukan kegiatan pengolahan karaginan dan dapat mengolahnya sendiri di masing-masing rumah warga sehingga dapat meningkatkan nilai jual dari rumput laut itu sendiri.
\end{abstract}

\section{Keywords : Rumput Laut, Karaginan, Gorontalo Utara}

\section{ABSTRACT}

Marine products produced in North Gorontalo Province include fish, shrimp, lobster, crabs, and seaweed. Seaweed is the most popular marine commodity. However, the innovation of how to process seaweed into processed products that have high selling power is still unknown to many fishers. The largest seaweed producing area in Gorontalo Province is in the North Gorontalo District, the center in Ponelo Kepulauan District. The Community Service activity aims to educate seaweed processing groups in Tihengo Village, which is the largest seaweed producing village in North Gorontalo to show how the correct method of utilizing seaweed is 
a food that has high selling value so that citizens' independence is built. By making the product itself through community-assisted groups. So that in addition to the environment is clean, it is expected that each family head will have a side business from the sale of processed seaweed so that it can be used as additional income for the family and able to reduce poverty as expected by the central and regional governments. The training carried out included processing seaweed-based products, namely training in carrageenan making. The final result that has been obtained from this service activity is that the community becomes skilled in carrying out carrageenan processing activities and can process it themselves in each of the residents' homes so that it can increase the selling value of the seaweed itself.

Keywords: Seaweed, Karagenan, North Gorontalo

\section{PENDAHULUAN}

Indonesia merupakan negara maritim dimana lebih dari 2/3 wilayahnya berupa lautan. Potensi kelautan di Indonesia cukup besar dan masih belum termanfaatkan sepenuhnya. Diantara 33 Provinsi di Indonesia, Gorontalo merupakan salah satu provinsi yang memiliki potensi laut yang melimpah baik hasil laut maupun pesona bawah lautnya. Provinsi Gorontalo berbatasan langsung dengan Kabupaten Boolang Mongondow di sebelah utara, sebelah selatan dengan Laut Tomini, sebelah timur dengan Samudra Pasifik, dan sebelah barat dengan Provinsi Sulawesi Tengah. Bentang wilayah Provinsi Gorontalo yang memiliki garis pantai diantaranya adalah Kota Gorontalo, Kabupaten Gorontalo Utara, Kabupaten Boalemo, Kabupaten Gorontalo Utara dan Kabupaten Pohuwato.

Filosofi masyarakat di Kabupaten Gorontalo Utara adalah "adat bersendikan syara, syara bersendikan kitabullah".Misi dari pemerintah Kabupaten Gorontalo Utara saat ini adalah mengembangkan Sistem Perekonomian yang Tangguh Berbasis Kerakyatan. Untuk mewujudkan visi sebagai kekuatan perekonomian yang tangguh di kawasan pantai utara Laut Sulawesi, perekonomian Kabupaten Gorontolo Utara diarahkan pada pengembangan sektor-sektor unggulan berbasis sumberdaya alam lokal yang didukung oleh upaya penciptaan nilai tambah melalui pengembangan kegiatan industri serta jasa-jasa penunjangnya, sehingga memiliki dampak yang besar bagi perekonomian wilayah secara keseluruhan. Untuk itu perlu diciptakan iklim yang kondusif untuk melakukan investasi, antara lain melalui penyediaan infrastruktur yang memadai, birokrasi perizinan yang efisien, serta situasi keamanan yang kondusif dan stabil.

Hasil laut yang dihasilkan di Provinsi Gorontalo Utara diantaranya adalah ikan, udang, lobster, kepiting dan rumput laut.

Rumput laut merupakan komoditas kelautan yang paling banyak diminati. Namun inovasi bagaimana cara mengolah

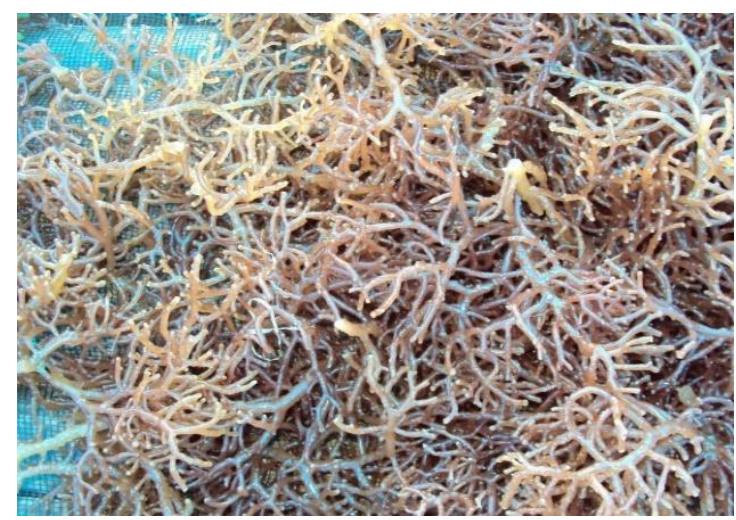

rumput laut menjadi produk olahan yang berdaya jual tinggi masih belum banyak diketahui oleh para nelayan. Daerah penghasil rumput laut terbesar di Provinsi Gorontalo ada di Kabupaten Gorontalo Utara pusatnya di Kecamatan Ponelo Kepulauan. 


\section{Permasalahan Mitra}

Desa Tihengo merupakan salah satu desa di Kecamatan Ponelo Kepulauan. Jarak dari kota Gorontalo ke Desa Tihengo, Kecamatan Ponelo Kepulauandapat ditempuh selama 1,5 jam. Untuk sampai ke Desa Tihengo satu- satunya akses yang dapat digunakan adalah dengan menggunakan transportasi darat menuju Pelabuhan Kwandang lalu dilanjutkan menaiki perahu ke lokasi desa. Desa ini sebagian besar kepala keluarganya berprofesi sebagai nelayan. Kondisi perekonomian warganya terbilang masih kurang sehingga berpengaruh terhadap taraf hidup masyarakatnya.

Gambar 1. Rumput Laut (Eucheuma cottonii)

Perlu dilakukan proses pengolahan pasca panen rumput laut menjadi olahan makanan yang bernilai jual tinggi. Beberapa ide dalam membuat olahan produk rumput laut diantaranya adalah karaginan, selai rumput laut, kerupuk rumput laut, koktail rumput laut, jelly drink rumput laut dan mie rumput laut. Proses pembuatannya sangat mudah hanya perlu dilakukan pra perlakuan yang bertujuan untuk menghilangkan bau amis rumput laut sebelum proses pengolahan lebih lanjut. Diharapkan setelah masyarakat diberi pengetahuan cara mengolah rumput laut dengan berbagai bentuk pelatihan, ada tindak lanjut dari kegiatan ini yaitu tata cara proses pengemasan dan tata niaganya. Proposal kegiatan Pengabdian Kepada Masyarakat

yang akan dilaksanakan oleh dosen Program Studi Teknologi Hasil Pertanian Politeknik Gorontalo ini bertujuan untuk melakukan edukasi kepada kelompok pengolahan rumput laut di Desa Tihengo yang merupakan desa penghasil rumput laut terbesar di Gorontalo Utara dalam rangka menunjukkan bagaimana metode yang benar dalam memanfaatkan rumput laut menjadi olahan makanan yang bernilai jual tinggi sehingga terbangun sikap kemandirian warga dengan membuat produk itu sendiri melalui kelompok binaan masyarakat. Sehingga selain lingkungan menjadi bersih diharapkan masing-masing kepala keluarga memiliki usaha sampingan dari hasil penjualan olahan rumput laut tersebut sehingga bisa dijadikan tambahan pendapatan keluarga dan mampu mengurangi tingkat kemiskinan seperti yang diharapkan pemerintah pusat maupun daerah.

\section{SOLUSI DAN TARGET LUARAN}

Melihat latar belakang di atas, maka solusi yang dapat dilakukan dalam menyelesaikan masalah di atas antara lain:

1. Mengatasi limbah rumput laut yang tidak dimanfaatkan oleh warga Desa Tihengo dengan memuat produk olahan rumput laut sebagai upaya peningkatan kesejahteraan keluarga,

2. Memberikan pengetahuan kepada warga Desa Tihengo dalam mengolah rumput laut menjadi aneka olahan rumput laut (misalnya mie rumput laut) berskala rumah tangga yang bernilai jual tinggi dari hulu hingga ke hilir

3. Sebagian besar warganya berpenghasilan rendah sehingga perlu adanya upaya meningkatkan penghasilan warga Desa Tihengo memiliki penghasilan melalui hasil olahan rumput laut.

Beberapa luaran yang diharapakan setelah terlaksananya program ini adalah:

1. Antusiasme masyarakat dapat tercermin dari partisipasi warga dalam bentuk kehadiran saat pelatihan dilaksanakan.

2. Hilangnya kebiasaan membuang limbah rumput laut di pantai dan mulai mengolah rumput laut menjadi aneka olahan makanan yang dapat dijual

3. Secara fisik, Desa Tihengo yang dahulunya bau dan kotor kini berubah menjadi kawasan biru yang bersih dan bebas sampah

4. Merupakan cikal bakal POSDAYA kampus Politeknik Gorontalo di Desa Tihengo yang membuka akses kegiatan penelitian dan pengabdian masyarakat untuk kedepannya sehingga ada 
hubungan timbal balik dan transfer ilmu pengetahuan antara kampus dengan desa binaan.

5. Terjalin kemitraan yang baik antara kampus Politeknik Gorontalo, Pemerintah Desa Kecamatan Ponelo Kepulauan dan Dinas Perikanan Kecamatan Ponelo Kepulauan sehingga bersama-sama merencanakan dan melaksanakan kegiatan khususnya di bidang perikanan pasca program selesai.

\section{METODE PELAKSANAAN}

Saat pelaksanaan program, tidak hanya materi dalam bentuk audio visual yang akan ditampilkan namun peserta juga diberikan manual/panduan bagaimana metode yang benar dalam melakukan pra dan pasca panen rumput laut. Bentuk kegiatan pengabdian masyarakat adalah pelatihan dan workshop yang dilakukan selama 2 hari. Masyarakat diajarkan bagaimana mengolah rumput laut menjadi karaginan dan bagaiamana tahapan dalam melakukan kegiatan agribisnisnya. Diharapkan setelah kegiatan ini selesai dilaksanakan, Desa Tihengo menjadi desa percontohan di Provinsi Gorontalo dimana mempunyai kekhasan yaitu daerahnya selain menjadi penghasil terbesar rumput laut juga merupakan sentra olahan

karaginan di wilayah Provinsi Gorontalo. Terbentuknya POSDAYA kerjasama antara Program Studi Teknologi Hasil Pertanian (HIMATEPA) dengan Pemerintah Desa Tihengo juga menjadi tujuan akhir kegiatan pengabdian kepada masyarakat ini sehingga terjadi adanya transfer ilmu

pengetahuan dan hubungan timbal balik yang baik antara kampus dengan masyarakat. Program tindak lanjut nantinya akan ada kegiatan supervisi secara berkala sehingga

tidak menutup kemungkinan muncul ideide baru dalam melakukan kerjasama kembali misalnya memanfaatkan sumberdaya Desa Tihengo yaitu ikan, udang dan kepiting dengan melakukan pelatihan pengolahan pasca panen hasil perikanan dan kelautan dan pelatihan manajemen agribisnis/pengelolaan usaha kecil dan menengah.

\section{Cara Mengolah Karaginan}

Pengolahan karagenan masih jarang dilakukan. Padahal alternatif lain bisnis pengolahan rumput laut ini prosesnya hampir sama dengan pengolahan agaragar. Jika pada waktu ekstrasi untuk mendapatkan memakai asam, maka untuk mendapatkan karagenan memakai basa. Bila penanganan pascapanen telah sempurna, proses selanjutnya dapat dilakukan secara sederhana untuk skala rumah tangga dan dapat juga dilakukan untuk skala industri.

\section{a. Produksi Karaginan untuk Skala Rumah Tangga}

1. Rumput laut direndam dalam air tawar selama $12-24$ jam, kemudian dibilas dan ditiriskan.

2. Setelah bersih rumput laut direbus dalam air dengan perbandingan rumput laut dengan air sebesar 1 : 15 , suhu $120 \mathrm{C}$ selama 15 menit. Perebusan memakai pressure cooker, selanjutnya dilakukan perebusan lagi tanpa tekanan pada suhu 10 C selama $2-3$ jam.

3. Rumput laut yang lunak dihancurkan dengan blender dan ditambahkan air panas $(90 \mathrm{C})$. Perbandingan 1 : 30. Hasilnya disaring dengan kain kasa halus.

4. Filtrat diendapkan menambahkan metil alkohol dengan perbandingan $2,5: 1$, bisa juga dengan menambahkan alkohol $90 \%$ atau membekukannya pada suhu $-10 \mathrm{C}$ 6 C selama $24-48$ jam.

5. Endapan yang bercampur alkohol disaring dengan kain kasa. Hasil saringan masih berupa keraginan basah. Filtrat yang beku perlu dicairkan dahulu untuk selanjutnya disaring lagi. 
6. Karagenan basah dikeringkan selama $3-4$ hari. Tepung karagenan dapat diperoleh setelah proses penggilingan.

\section{b. Produksi Karagenan Untuk Skala Industri}

1. Rumput laut dicuci dengan air tawar kemudian dikeringkan sampai kadar air menjadi 15 - 25 $\%$.

2. Rumput laut kering diesktraksi dengan ditambah air panas dan kalsium hidroksida atau natrium hidrosida. Selama ekstraksi terjadi penghancuran dan hasilnya berupa pasta. Penghancuran ini bertujuan untuk memperluas permukaan rumput laut sehingga proses pelarutan karaginan akan lebih mudah.

3. Pasta selanjutnya dimasukkan ke tangki atau bejana dan dipanaskan selama 24 jam pada suhu 90 - 95 C.

4. Setelah itu pindahkan ke tangki lain atau bejana dan dipanaskan selama 24 jam pada suhu $90-95$ C.

5. Setelah mendidih disaring dengan filter aid atau tanah diatomea. Hasilnya disaring lagi dengan filter press.

6. Filtrate yang dihasilkan dipompa ke dalam tangki yang berisi propil alkohol dan akan didapatkan serat karaginan.

7. Serat karagenan dipress, kemudian dicuci dengan alkohol segar dan dipress lagi. Lembaran karagenan yang didapat dikeringkan dengan rotary dryer. Untuk mendapatkan tepung karaginan lembaran tersebut digiling.

\section{c. Standar Mutu}

Indonesia belum mempunyai standar mutu karaginan. Standar mutu yang dikenal adalah EEC Stabilizer Directive dan
FAO/WHO Specification. Tepung karagenan mempunyai standar $99 \%$ lolos saringan 60 mesh, tepung yang terendap alcohol 0,7 dan kadar air $15 \%$ pada RH 50 dan $25 \%$ pada RH 70

\section{HASIL DAN PEMBAHASAN}

Kegiatan pengabdian masyarakat ini ditujukan kepada 2 (dua) kelompok mitra yang bertempat tinggal di Desa Tihengo, Kecamatan Ponelo Kepulauan, Kabupaten Gorontalo Utara, Provinsi Gorontalo. Dua kelompok tersebut adalah kelompok mitra "Karya Bersama" (diketuai oleh Ibu Teti Usman) dan "Mekar Jaya" (diketuai oleh Ibu Asnawati) dimana kelompok tersebut fokus dipemberdayaan masyarakat dalam bentuk usaha pengolahan rumput laut.

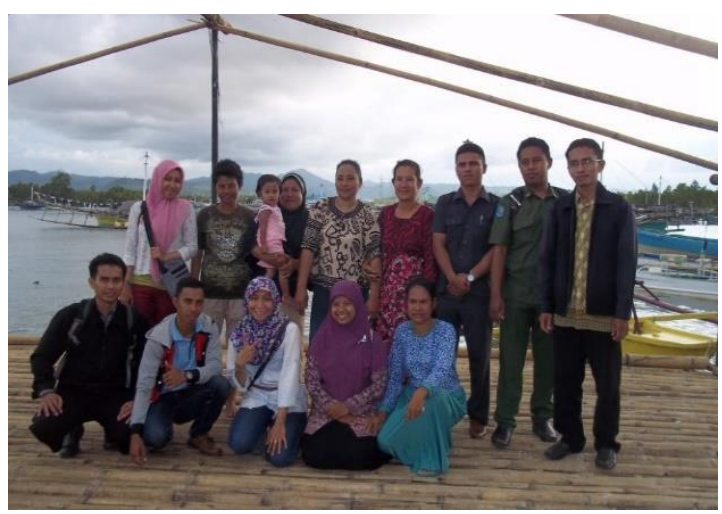

Peserta yang mengikuti kegiatan ini berjumlah kurang lebih 20 orang yang berasal dari ibu rumah tangga dan nelayan di desa tersebut. Kegiatan ini hanya berlangsung sehari dan bertempat di Saung Pertemuan milik Pemerintah Desa Tihengo dan berlanjut ke rumah salah satu warga saat pelaksanaan praktek pengolahan rumput laut. Program tindak lanjut nantinya akan ada kegiatan supervisi secara berkala sehingga tidak menutup kemungkinan muncul ide-ide baru dalam melakukan kerjasama kembali misalnya memanfaatkan sumberdaya Desa Tihengo yaitu ikan, udang dan kepiting dengan melakukan pelatihan pengolahan pasca panen hasil perikanan dan manajemen agribisnisnya. 


\section{DAFTAR PUSTAKA}

Anggadireja, J.T., Istini, A. Zatnika dan Suhaimi. 1986. Manfaat dan Pengolahan Rumput Laut. Badan Pengkajian dan Penerapan Teknologi Jakarta. Hal 128-135

Asnawi. 2008. Pengaruh Kondisi Presipitasi terhadap Rendemen Sifat Karaginan dari Rumput Laut (Eucheuma cottoni). Surakarta

Distantina, S dan Dyartanti, E. R. 2007. Ekstraksi Karaginan dari Rumput Laut (Eucheuma cottoni) menggunakan pelarut $\mathrm{NaOH}$. Surakarta. 